UDC 376-056.34(495)

DOI https://doi.org/10.32782/humanitas/2021.3.6

\title{
Paraskevi KALTSOUNI
}

PhD Student majoring in Philology, Ternopil Volodymyr Hnatiuk National Pedagogical University, 2, M. Kryvonosa str., Ternopil, Ukraine, 46027

ORCID: 0000-0001-8991-6039

To cite this article: Kaltsouni, P. (2021). Parallel support: a new educational approach for students with autism in Greek educational system. Vvichlyvist. Humanitas, 3, 37-45, doi: https://doi.org/10.32782/humanitas/2021.3.6

\section{PARALLEL SUPPORT: A NEW EDUCATIONAL APPROACH FOR STUDENTS WITH AUTISM IN GREEK EDUCATIONAL SYSTEM}

Introduction. In the last two decades in the Greek educational system, the co-education of students in the classes of the General School has been implemented in a high grade. This means that students with disabilities or other educational needs are not required to attend exclusively the Special School, but can attend the General School, with the support of suitably qualified Special Education and Research Staff as well as Special Support Staff.

Purpose of the work. The basic aim of this article which refers to this very important institution of Parallel Support is to define Parallel Support, presenting the advantages and disadvantages of this institution. Finally, there is a reference to the difficulties and challenges that arise nowadays, regarding the specific institution and the conditions for its proper and uninterrupted operation.

Methodology. For this purpose, a bibliographic search of descriptive-analytical nature took place, through the offered bibliography and articles. In particular, a search was made on the Internet database, law libraries and in electronic libraries of domestic and international level using the keywords. Due to the interest of the topic and its current character, a plethora of material, books, articles, as well as practices of international and pan-Hellenic conferences and magazines were identified.

Scientific novelty. The study of the application of parallel support in Greece is an important undertaking, as it provides an appropriate starting point for kids with special needs in today's global society.

Conclusions. It is certain that Greek education still encounters great difficulties in trying to synchronize it with accession policies. And a problematic application always carries the risk of leading sound policies in disrepute. On the other hand, the permanent postponement of membership pending the appropriate conditions objectively leads to perpetuation of inherited pathogens. Utilization, in to the maximum extent possible, of the advantages provided by the existing integration policies and, at the same time, the constant need to ensure the broader necessary for our country, it is convincingly promoted as the most appropriate practice.

Key words: parallel support, inclusive education, special needs, Greek educational system.

\section{Параскеві КАЛЬЦУНІ}

аспірантка за спеціальністю «Філологія», Тернопільський національний педагогічний університет імені Володимира Гнатюка, вул. М. Кривоноса, 2, м. Тернопіль, Украӥна, 46027

ORCID: 0000-0001-8991-6039

Бібліографічний опис статті: Кальцуні, П. (2021). Паралельна підтримка: новий освітній підхід до учнів з аутизмом у системі освіти Греції. Bвічливість. Humanitas, 3, 37-45, doi: https://doi.org/10.32782/humanitas/2021.3.6

\section{ПАРАЛЕЛЬНА ПІДТРИМКА: НОВИЙ ОСВІТНІЙ ПІДХІД ДО УЧНІВ 3 АУТИЗМОМ У СИСТЕМІ ОСВІТИ ГРЕЦЇ̈}

Упродовж останніх двох десятиліть освітня система Греиії активно впроваджувала спільне навчання в загальноосвітній школі. Це означає, щзо учні з інвалідністю або іншими освітніми потребами мають змогу навчатися не лише у спеціалізованих школах, а й у загальноосвітніх школах за підтримки науково-педагогічного та допоміжного персоналу, щзо має відповідну кваліфікацію.

Головна мета статті - надати визначення поняття паралельної підтримки, продемонструвати переваги та недоліки иієї системи, зробити висновки про нинішні труднощі та загрози, щ⿻о постають у процесі реалізації паралельної підтримки та стосуються ї̈ належного та безперервного функціонування.

Із иією метою було виконано описово-аналітичне дослідження запропонованих літературних джерел та статей. Зокрема, за ключовими словами було досліджено джерела з мережі Інтернет, бібліотек юридичої літератури 
та електронних бібліотек національного та міжнародного рівнів. Розглянуто великий обсяг матеріалів, книжок, статей, а також практик, щуо були описані на міжнародних та грецьких конференціях, а також у періодичних виданнях.

Дослідження засобів упровадження паралельної підтримки в Греції є важливим завданням, оскільки ия система дає поштовх для розвитку дітей з особливими потребами в сучасному глобалізованому суспільстві.

Беззаперечно, намагаючись синхронізувати систему паралельної підтримки із заходами з розщирення доступності послуг для людей з особливими потребами, система освіти Греиії все ще зустрічається зі значними труднощами. А проблематичне впровадження системи завжди супроводжується ризиком дискредитації раціональних заходів. 3 іншого боку, неможливо безкінечно відкладати забезпечення громадою належних умов для дітей з особливими потребами: ие об'єктивно призводить до укорінення несприятливих умов. Максимально можливе використання переваг, які надаються існуючими заходами з інтеграції людей з особливими потребами до суспільства, та водночас постійна потреба забезпечити належну інклюзивну освіту в нашій країні, переконливо демонструють необхідність паралельної підтримки як найбільш оптимальної практики.

Ключові слова: паралельна підтримка, інклюзивна освіта, особливі потреби, освітня система Греції.

\section{Introduction}

In the Greek educational reality for a few years now operates the institution of parallel support, according to which a teacher has supporting role next to a student with special needs within it normal order. This student may be mentally retarded, diffuse developmental disorder, learning difficulties, vision, hearing problems behavioral, motor, attention deficit or various other forms of disability.

According to the revised version of DSM $\mathrm{V}$ (American Psychiatric Association (APA), 2013) Autism spectrum disorders occur mainly in two key areas related to social communication and stereotypical patterns of behavior, activities and interests noting disproportionately large deficiencies in both communication skills and social skills, reduced social approach (Gena, 2002) and interaction, reduced social and emotional reciprocity, empathy (Saitis, 2008) and difficulties in verbal or non-verbal communication. The institution of Parallel Support helps these children, especially to learn how to integrate, coexist and function harmoniously in the whole. To learn not to be afraid and to have self-confidence. The person of parallel support is the only "Specialist" who sees the child in a spontaneous environment and helps him right where he is suffering. But beyond the weakening in social communication, Tsouli in his research (2015) also show a significant impairment in comprehension and the use of language pointing out how people with its disorders autism spectrum are performing poorly in the fields related to morphology, syntax, grammar and vocabulary while they also have significant deficiencies in both their expressive and receptive language profile (Davlanti, 2019). All of the above are necessary to be explored in order to establish the role of the institution of parallel support in the integration of students with autism in regular school. Through this study, the response of this institution to the specifications of their inclusion children with special needs in the regular classroom, the intensity of support and whether a redefinition is needed in order to be able to contribute to the integration of students with autism in non-exclusion schools. Based on the deficits that people with spectrum disorders show autism in both communication and social skills, and regarding the deficiencies noted in the existing literature to students with autism in Education, this study is really significant. Through a literature review in depth, representing a method that the literature reviewer chooses from an array of strategies and procedures for identifying, recording, understanding, meaning-making, and transmitting information pertinent to a topic of interest, it became obvious the great matter of inclusive education and parallel support as well.

The relevance and the latest publications. The most recent law on special education (3699/2008, article 6) in Greece states that children with special educational needs and/or disabilities have the right to attend general school always with the support of properly qualified teaching staff. In other words, it is the coexistence and co-teaching of all children regardless of individuality and educational needs (Liodakis, 2000). In Greece the model of co-teaching is called parallel support.

In parallel support the special education teacher is with the student who has special educational needs and/or disability in the general class and helps him, while at the same time the teacher teaches all the children. The students provided by the parallel support are children who can attend the general education curriculum with the appropriate individual support. Students with severe special needs can also study at this institution when there is no other framework of special education 
and training in the area where they live (SMEAE, department of integration) or when it is judged by KEDDY based on an opinion that will determine the hours of parallel support that will accepts the student. The support is provided by the special educator on a permanent and planned basis. The KEDDY after the diagnostic evaluation that they carry out in the child and with the necessary opinion are responsible in judging a more educational context is more suitable for this. Thus, the parents request the provision of parallel support for their child and receiving the relevant opinion from the KEDDY is submitted to the management of the school unit and finally notified to the Ministry of Education (Law 3699/2008).

Advantages - Disadvantages of Parallel Support. Many studies have looked at whether co-education in parallel support is effective or not. For this reason, two opposing views have prevailed. The first, which supports this model and the second, which considers it unrealistic and fair (Taylor \& Harrington, 2003). This section will discuss the benefits of co-teaching in the institution of Parallel Support, which according to research that has examined the attitudes of teachers, students, parents and school administration is a very promising positive integration practice (McDuffie et al., 2007).

The application of this model of education offers both professional benefits to teachers, as well as academic, social and emotional benefits to students (Strogilos et al., 2015). The education of children with special educational needs and/or disability in the general classroom together with students of formal development brings benefits to their cognitive and social skills (Anderson et al. 2007). According to a research by Arvanitidou (2018) general education and special education teachers with more than 10 years of service recognized the benefits of children participating in the institution of parallel support in terms of social, emotional and academic sector. It also reduces racism, stigma and marginalization, phenomena created by the removal of the child from the classroom. Research by Koutroumba, Vamvakaris and Theodoropoulos (2008) showed that a large number of teachers who participated reported that it contributes to the social integration of children with special educational needs and/or disability, but also to the removal of prejudices. The cognitive part of children with special educational needs and/or disability develops more by improving their academic performance, as well as increases their self-confidence by interacting and developing friendships with their peers (Anderson, 1997). Improving children's cognitive performance may also be related to having two teachers in the classroom. Teachers report that children with special educational needs and/or disabilities benefit from the social standards of typical developmental students related to their behavior, functionality, work method and knowledge (Panagiotou, Evangelinou, Doulkeridou, Koidou \& Mouratidou, 2009). In addition to the academic and social benefits, inclusive education also provides benefits in the psycho-emotional field of students with special educational needs and/or disability, enhancing their sense of "belonging" which is a prerequisite for learning (Shaffner \& Buswell, 2004). The same is shown by the research of Arnidou (2007) where the participants talk about the progress of these students in the psycho-emotional field, since children socialize, communicate and play with other students in the class, gaining various experiences living the rhythms of a normal class.

Co-education offers benefits to children with disabilities, but also to those without disabilities, since educational strategies are modified (Tsiouli, 2015). At the social level, students of formal development perceive the difficulties faced by these individuals by developing feelings of interest, social sensitivity and solidarity, support them, help them and develop better communication, social and emotional skills (Anderson et al., 2007). This fact is confirmed by research data that according to teachers, children with disabilities who attend co-education classes show greater understanding and acceptance of diversity and respect for others, gain strong self-esteem and build friendships more easily (McCarty, 2006). Arnidou's (2007) research showed that students of formal development accept the different, deconstruct stereotypes and help them to function democratically and equally in their later life, understanding the different needs of each individual and gaining emotional competence. The general behavior of students without disabilities can change and become more positive regarding the integration of students with special educational needs and/or with disabilities (Panagiotou, Evangelinou, Doulkeridou, Koidou \& Mouratidou, 2009). In short, it promotes the emotional and social 
development of students of typical development in terms of support, acceptance and respect while promoting the democratic feeling (Soulis, 2008). Also, children in co-teaching classrooms can improve their learning needs by receiving high quality educational services (Sileo \& Van Gardenen, 2010). Also, the education of children with special educational needs and/or disability in the school of their neighborhood helps them in their subsequent social and professional integration (Kypriotakis, 2001). Students with low performance are favored by the practices and techniques of inclusive education, since with the modifications of the curriculum, alternative teaching methods and the presence of specialized staff the class coherence becomes greater (Anderson et al. 2007). Even «good» students have opportunities to participate in enriched work, while children at risk of school failure receive additional teaching support to improve their academic performance (Friend \& Cook, 2013). Thus, it is understood that more favorable learning conditions are created for all students in the class, while at the same time the ratio of students per teacher is reduced, making the educational process easier and more efficient (Mavropalias, 2013).

However, teachers also benefit from the parallel support and the model of co-teaching, since through their cooperation they can and exchange useful knowledge and skills. More specifically, educators acquire more knowledge with academic content, while general educators improve their teaching strategies and behavior management, as well as acquire some knowledge of special education (McDuffie et al., 2007). In general, they develop a spirit of collaboration by creating a wide range of teaching methods that will be relevant to all students (Power-deFur \& Orelove, 1996). In this way they evolve and satisfy their need for selfimprovement. Also, through the model of inclusive education, the parents of the children are favored, since they come in contact with other parents, discuss and are active in solving common problems.

In addition to the benefits for students, teachers and parents, inclusive education also has a positive impact on a humanitarian level, as discrimination and prejudice are eliminated, a climate of social solidarity is created, equal participation of all children in education is ensured, and the policy of exclusion accepting diversity (Soulis, 2002). However, apart from its advantages, several researchers due to the inability of the education system to meet the requirements and conditions for the inclusion of children with special educational needs and/or disability in general school express several doubts about its success and are against it.

Bateman and Bateman (2002) argue that general education is not suitable for such students, as there is no individualized teaching or special support from speech therapists and occupational therapists in special schools (McCarty, 2006). In a study conducted in Australia, teachers reported some disadvantages of inclusive education, the main ones being: the time to prepare the teacher to be informed by the psychologist about issues related to the education of people with special educational needs and/or disability, the time preparation for the teaching of these students and the behavioral problems that arise in the general classroom hindering the learning of other children (Anderson et al., 2007). The problem of the time of special preparation for the co-education course in parallel support was also highlighted by a study by Davlanti (2019). The same was shown by a research by Soulis (2008) on the parents of children of typical development, who had doubts about the quality of education provided to their children when they first came in contact with such a learning environment. Greek research has shown that negative results were recorded for typically developing children through inclusive education (Zoniou - Sideri and Vlachou, 2006).

Also, in order for co-education to take place in the institution of parallel support, it is necessary for the general education educators to be trained in special education issues. However, their training is characterized as insufficient after research by Panteliadou \& Patsiodimou (2000) and Panteliadou (2004). For this reason, participants in a research by Mavropalias (2013) stated that general education teachers participated little or not at all in the formulation of the individualized educational program. For this reason, the training of general education teachers is considered necessary since they either have incomplete knowledge or do not have it at all so that they can integrate students with special educational needs and/or disability into the classroom (Avramidis \& Kalyva, 2007).

Another disadvantage that applies mainly to the Greek reality and is found in the implementation of the institution of parallel support is the lack of logistical infrastructure, the difficulty 
of the curriculum, the lack of a specific curriculum for students with special educational needs and/ or disability, the lack of time and willingness to collaborate and the size of the classrooms. For this reason, the need for financial resources from the political leadership to cover these problems is considered imperative (Pagotou, 2018).

In addition, a serious disadvantage is the serious disorders that some students experience, since many times due to their inappropriate behavior (anger, stereotypes, etc.) they interrupt the lesson in the general class, are isolated and stigmatized. By disrupting the lesson in this way, the rest of the normal developmental students cannot develop to a degree that would have been possible without these children in the classroom. An issue also arises from the abstention of additional supportive intervention, i.e. co-education in the form of simple coexistence. Simple coexistence does not provide systematic support to these students to help them acquire social skills and build relationships with other children. In addition, special interventions are necessary in the general classroom, so that students with special educational needs and / or disabilities receive the appropriate education, since without it there is a risk of implementing full inclusive education, which although it is a democratic idea can not practically lead to exclusion and segregation (Kavale \& Mostert, 2004).

Finally, reservations are identified regarding the long-term benefits of inclusive education in the field of social inclusion of students with special educational needs and/or disability. There is a view that the friendships that are created in the school after the graduation of the students are lost and with them disappear the long-term benefits of the co-education. School is an artificial environment and can not affect the relationships in the lives of children during their lifetime. Thus, their relations in the local community should be strengthened, but also additional measures should be taken for their socialization (Brown \& Shearer, 2004).

The most negative element of the institution is the stigmatization and marginalization of students due to their existence and support by a special educator. Many classmates understand the role of the special education teacher and when they are not aware, informed and have not learned to accept the difference, they reject everything that is foreign to them. Support for the student seems like a weakness in their face and for this reason they are stigmatized and marginalized.
Placing a student with special educational needs and/or disability in general education does not ensure his / her social participation in this environment, but he/she may face difficulties, such as limited friendships and lack of acceptance from other children (Koster, Pijl, Nakken \& Van Houten, 2010). Also, according to Giangreco (2010) excessive teacher help with personalized support can lead to negative consequences, such as stigma. Research by Loire (2016) showed in terms of the essential relationships of these students with their classmates outside of school that the latter do show a positive attitude, but in fact rarely have contact with them, a fact that is confirmed by other research (Patsidou, 2010) showing that the benefits of inclusive education in the social sector within the school environment are temporary.

As for the advantages of the integration classes, this is the specialized program that they offer and rely exclusively on the abilities of each student, covering their learning gaps and offering a smooth integration of these students in the general class, resulting in them feeling more capable by gaining self-esteem. The special education teacher evaluates the students of the integration departments, what difficulties they face and according to them prepares a program with which they will be overcome in order to be re-integrated in the general class.

According to Christaki (2011) the specialized educational staff together with a specialized program adapted to the abilities of the students leads to an improvement of the school performance and behavior. The ability to adapt the program to the needs of the student and not the other way around is the strongest point of the integration classes that have the ultimate goal to join the regular class following the rhythm of the other students (Gena, 2002). The operation and approach of the integration departments there is studentcentered and the teaching methodology is more appropriate, contributing to the creation of a positive result (Patsali, 2008). In fact, students in integration classes often have problems with their classroom learning process. With the integration departments they cover these gaps and the shortcomings that they have and can again follow the flow of the general order. According to Kastanidou (2000) the students who participated in Integration Departments developed social skills making it easier for them to integrate into the pedagogical and social development of the classroom, but also of the school in general, 
while due to the small number of students who participate in individual and Individualized teaching practices performed by children experience success by giving them confidence, while at the same time improving their performance in the general classroom (Patsali, 2008).

Also, according to Matsagoura (2000), the students of the Integration Departments, in addition to their development in the cognitive part, developed other skills making them more accepted by their teachers and classmates, a fact that motivates them and encourages them to have a more active participation in school activities. Students develop skills that allow them to participate in general classroom activities as well, making them acceptable to their teachers and classmates by creating opportunities for their active participation (Matsagoura, 2000). Research by Patsidou (2010) states that in the first days the students of the Integration Departments feel embarrassed and afraid of being cut off from the classroom environment, however their attitude gradually changes and due to the support they receive they develop their self-perception, cultivating their selfesteem. at the same time communication skills.

Regarding the disadvantages of the integration classes is the possible stigmatization of these students due to their removal for a few hours from the general classroom. Some classmates may make jokes because of the difficulties they face and how they have to go to the integration department to respond. For this reason, students in integration classes can be marginalized simply because they are missing a few hours from their classroom to study in the integration department. There are cases in which children of normal development reject, stigmatize these children by discouraging their social progress (Sabornie, 1987) due to the departure of students with special educational needs and/or disability to be transferred for a few hours to the Department of Integration. Also, Barbas and his colleagues (2006) found that the students of the Integration Departments did not hang out with their classmates while being isolated, while sometimes they received playful comments.

Finally, a disadvantage is the large number of students who study in the integration department, since many students by law enter without an opinion from KESY and also rarely the required number is observed. As a result, there are many students with non-uniformity in their learning profiles, creating problems in the design of a specialized program by the special education teacher who needs more time. Problems are created in the organization of the school environment, since in many cases an Integration Department is created with many students who have increased needs, but the time allotted to them is short. The large number that exists in the Integration Departments is mainly due to the fact that students who do not have an official diagnosis from KESY can enroll (Bilanaki and Tragoulia, 2010).

According to Vlachou (2006) special educators cited the lack of cooperation with general education teachers as an issue that affects their work. In general, good cooperation is a positive factor for the successful implementation of support programs.

According to Anderson and his collaborators, the class teachers do not feel ready to meet the demands of the students due to their insufficient knowledge and lack of specialization (Anderson et al., 2007). General education teachers are unfamiliar with the use of such practices and their training in special education is incomplete, while they are attached to the teaching content and the curriculum, considering themselves class leaders. For this reason, special educators rarely take the lead in teaching and are usually treated as assistants rather than equal partners (Friend et al., 2010).

General education teachers report as another problem of cooperation their lack of education and training in Special Education, creating feelings of inadequacy in terms of receiving effective integration strategies (Panteliadou \& Kotoulas, 1997).

One of the problems they face every year is the non-recruitment or untimely recruitment of substitute special education teachers to staff the program. In the Greek reality, many schools that are in urgent need of special staff, recruitments can be made in the middle of the year or not at all, thus wasting valuable time for the support and development of students. The same is demonstrated by a research by Mavropalias (2013) since many times the recruitments are not made from the beginning of the school year, but can be done 2-3 months or more, wasting valuable time the student. Thus, for the Greek data, there are programming problems for which the Ministry of Education is responsible.

The cooperation between the special educator, the principal and the child's family is considered 
important since working in a reciprocal relationship complements each other and the intervention will be more effective with many positive elements. Thus, for a successful education in a school unit, their cooperation is a necessary condition (Kastanidou, 2000). Promoting collaboration with teachers is one of their main concerns, which is confirmed by teachers as they state that in the schools where the principals work, they work closely with them and with the parents of the children (Pedagogical Institute, 2008). Everyone benefits from such a collaboration, as students feel more familiar at school and consider it an extension of their family environment, parents have a clear picture of their children and teachers get relevant information about children that will help them solve various problems (Saitis, 2008). Continuous communication, dialogue, systematic exchange of information and continuous feedback are some of the elements that must exist between these three aspects, in order to jointly formulate the goals that are expected to be achieved by the student (Patsalis, 2008). Various practices include principal and teacher meetings with parents about children's progress, setting up support groups with parents to discuss children's educational needs, informing parents of any changes to the curriculum, and collaborating with each other on solving any problem that arises within the school, can only have a positive impact on the educational process (Tikly, 2004).

Another form of cooperation is with external bodies (e.g. child psychologists, speech therapists, KEDDY). When the studentreceives an intervention from an external body, it would be important that the information resulting from their meetings is transferred to the special educator of the school to have a complete picture and to adjust the goals or the educational process accordingly.

A prerequisite for ideal working conditions is the same workplace and in this case the school classrooms. Appropriate infrastructure, appropriate rooms equipped with supervisory tools, support materials and training programs should be in place to carry out as intensive and targeted intervention as possible. For this reason, there is an urgent need for funding from the state so that there are rooms and the lesson is not done in corridors or other inappropriate places, but also shaped according to various supervisory tools and support material that will help in learning procedure.
Furthermore, in addition to the material and technical equipment, the human resources of the school should be based on the timely recruitment of special educators from the beginning of the year and not in the middle. An agreement is also made by Christakis (2011) research which mentions the lack of rooms for the operation of the integration departments and generally lacks supervisory material, while most of the time the teachers themselves make their own material. However, the competent bodies do not respond to their request for supervision material. Many literature reports emphasize the importance of logistics infrastructure in effective education. A suitable school workplace with the reinforcement of support material plays a crucial role in shaping the learning environment, which can creatively activate students in building knowledge. (Matsagouras, 2000). In general, it is necessary to provide space and equipment that will allow the development of the main curriculum (Christakis, 1994).

Conclusions. The idea of effective integration of children with special educational needs and/or disabilities in the public school and the provision of the necessary educational and social assistance has experienced the latest decades of fervent support in Greece as well. However, serious shortcomings, difficulties and obstacles have made this happen of perspective problematic.

Especially in conditions of generalized and acute financial crisis, such as the crises that Greek society has been facing since the end of the last decade, the situation is deteriorating rapidly, as not only the securing the necessary resources is problematic but also the positive attitudes towards the most vulnerable in poverty our fellow citizens are usually softened.

To determine the benefits of parallel support and whether, indeed, children with Autism Spectrum Disorder succeed in integrating into society as a whole, and in particular into school environment, it is proposed to conduct a timeless research.

Everybody's belief is, however, that even in such a difficult time it is the responsibility of modern societies to take care of it continuously realization of the integration of all children in educational structures, and ensure that all necessary conditions are met. Undoubtedly, those related to the appropriate training and awareness of the teaching staff. 


\section{Prospects for further exploration}

Inclusive schools need to be characterized by creating conditions for cooperation and dialogue between teachers and everyone of the members that make up the school team. The inclusion is not necessary to concerns only one student, the one with autism, but all students with use different strategies and work on many different ones flat. It needs to be acknowledged that all children learn in different way. Collaboration and interaction support every effort integration and creating situations through which all students can develop on a cognitive and social level.

In addition, it will future research could be conducted with the same objective, but with their participants parents of children with ASD or general education teachers who have include one or more children with autism in their class. A contingency cross-referencing the results with those of the present study would be interesting. Since this is a novel area of study, it is important that future studies have first of all increased sample sizes in the research, as autism is still a relatively rare disorder from a population standpoint. Therefore it is not as easy to obtain large sample sizes as done in studies with autism children. Nevertheless, larger sample sizes should be used. It would also be important to investigate the point of view of people with ASD themselves, who will could, having completed their education with the institution of parallel support the effectiveness of this measure in relation to the smooth their socialization. The possible research can be carried out, after some have passed years of implementation of parallel support in Greece.

\section{REFERENCES:}

1. Anderson C. J. K., Klassen R. M. and George G. K. (2007). Inclusion in Australia. What teachers say they need and what school psychologists can offer. School Psychology International, 28(2), 131-147.

2. Arnidou, K. (2007). The teachers of parallel support in the context of pedagogy of integration. AUTh. Paedagogical Department Primary Education.

3. Arvanitidou, K. (2018). The attitudes of primary school teachers general and special education regarding the co-education of students with and without special needs within general schools. Department of Educational and Social Policy. Thessaloniki: University of Macedonia.

4. Avramidis, E. \& Kalyva, E. (2006). Research methods in special needs: Theory and practice. Athens: Papazisis.

5. Barbas, G. et al., (2006). Assessment of learning characteristics Primary school students with learning difficulties. Pedagogical Review, 42, 121-140.

6. Bateman, D., \& Bateman, C. (2002). What does a principal need to know about inclusion? Arlington, VA: ERIC Clearinghouse use on Disabilities and Gifted Education, ERIC Document Reproduction Service No. ED473828.

7. Brown P. I. \& Shearer J. (2004). Challenges for inclusion within a quality of life model for the 21 st century. In Mitchell, D. (ed.). Special educational needs and inclusive education: Major themes in education, Vol. II (pp. 139-156). New York: Routledge Falmer.

8. Christakis, G.K. (1994). Special education issues. Athens: Telethrion.

9. Christakis, G.K. (2011). The education of children with difficulties. Introduction to special education. Athens: Interaction.

10. Davlanti, G. (2019). Investigating teachers' perceptions regarding with inclusive education. 2nd Panhellenic Critical Education Conference. The critique education for social justice. National and Capodistrian Athens university.

11. Friend, M., \& Cook, L. (2013). Interactions: Collaboration skills for school professionals. Columbus, OH: Merrill/Pearson.

12. Gena, A., (2002). Autism and pervasive developmental disorders. Athens: Edition of the author.

13. Georgiou, S. (2000). School-family relationship and child development. Athens: Greek Letters.

14. Giangreco, M. F. (2010). Utilization of Teaching Assistants in Inclusive Schools: Is It the Kind of Help that Helping Is about? European Journal of Special Needs Education, 25(4), 341-345.

15. Kastanidou, S. (2000). Social change and family: Socialization family operation. Modern education, 20.

16. Kavale, K. A., \& Mostert, M. P. (2004). Social skills interventions for individuals with learning disabilities. Learning Disability Quarterly, 27(1), 31-43.

17. Koster, M., Pijl, S. J., Nakken, H., \& Van Houten, E. (2010). Social participation of students with special needs in regular primary education in the Netherlands. International Journal of Disability, Development and Education, 57(1), $59-75$.

18. Koutrouba, K., Vamvakari, M., \& Theodoropoulos, H. (2008). SEN students' inclusion in Greece: factors influencing Greek teachers' stance. European Journal of Special Needs Education, 23(4), 413-421. 
19. Kypriotakis, A. (2001). A pedagogical. A school for all children. Modern perceptions of education and training of children with disabilities in life and learning. Athens: Greek Letters.

20. Liodakis, D. (2000). Educational programs for the blind. Athens: Atrapos.

21. Loire, M. (2016). Typical students' views and feelings about integration student with a disability. In G. Papadatos, S. Polychronopoulou \& A. Bastea (Ed.). 5th Panhellenic Conference of Education Sciences, 19-21 June 2016 (pp. 764-776). Athena.

22. Matsagouras, H. G., (2000). Collaborative Teaching and Learning. Athens: Grigoris.

23. Mavropalias, T., (2013). Evaluation of the Parallel Support program. Florina: Pedagogical Department of Primary Education.

24. McCarty, K. (2006). Full Inclusion: The Benefits and Disadvantages of Inclusive Schooling. An Overview. ERIC Document Reproduction Service No, ED496074.

25. McDuffie, A., Turner, L., Stone, W., Yoder, P., Wolery, M., \& Ulman, T. (2007). Developmental correlates of different types of motor imitation in young children with autism spectrum disorders. Journal of autism and developmental disorders, 37(3), 401-412.

26. Panteliadou, S. (2004). The mapping of the Special Education area. Presentation at the conference "Mapping Curricula of Special Education" of Pedagogical Institute. EPEAEK - Ministry of Education, April 25, 2004, Thessaloniki.

27. Panteliadou, S. \& Kotoulas, V. (1997). School Integration of People with Special Needs Educational Needs: A suggestion. Contemporary Education, 96/97, 136-146.

28. Panteliadou, S., \& Patsiodimou, A. (2000). Attitudes and views of teachers for training in special education. Thessaloniki: Ministry of Education, 2nd Community Framework Support, Educational Research Center.

29. Patsalis, Ch. (2008). The institution of integrating students with special learning difficulties in the Greek educational reality. Scientific Step, 9.

30. Patsidou, M. (2010). Continuous education of children with or without educational needs. Stops teachers and students in secondary education. Aristotle University of Thessaloniki.

31. Power-Defur Lissa A. Power-Defur Orelove Fred P. Pod.(1996) Inclusive Education. Aspen Publishers.

32. Sabornie, E. J. (1987). Bi-directional social status of behaviorally disordered and nonhandicapped elementary school pupils. Behavioral Disorders, 13(1), 45-57.

33. Saitis, Ch. (2008). The principal at the public school. Athens: Ministry of Education, Pedagogical Institute.

34. Shaffner, C.B. \& Buswell B.E. (2004) What do we really know about inclusive schools; A systematic review of the research evidence, in Mitchell D. (ed). Special education needs and inclusive education: Major themes in education. Vol. II (p.p. 295-313). New York Routledge Farmer.

35. Sileo, J. M., \& van Garderen, D. (2010). Creating optimal opportunities to learn mathematics: Blending co-teaching structures with research-based practices. Teaching Exceptional Children, 42(3), 14-21.

36. Soulis, S. (2002). From the school of separation to a school for all. Athens: Print

37. Soulis, S.G. (2008). A school for everyone. Athens: Gutenberg.

38. Strogilos, V., Tragoulia, E., \& Kaila, M. (2015). Curriculum issues and benefits in supportive co-taught classes for students with intellectual disabilities. International Journal of Developmental Disabilities, 61(1), 32-40.

39. Taylor, G. R. \& Harrington, F. T. (2003). Educating the disabled. Enabling learners in inclusive settings. Lanham, Maryland and Oxford: Scarecrow Education.

40. Tickly, L. (2004.) Education and the new imperialism. Comparative Education, 40(2), 173-198.

41. Tsiouli, K. (2015). Happiness as a factor in accepting dysfunction: a interdisciplinary research - educational proposals. Ioannina: University of Ioannina. Ioannina.

42. Vlachou, A. (2006). Role of special/support teachers in Greek primary schools: A counterproductive effect of 'inclusion' practices. International Journal of Inclusive Education, 10(1), 39-58. 